\title{
EU Innovation Performance Policies and the Economic Crisis: Innovation Policy and the Political Failure of Italy
}

\author{
Dr. Marco Boschele (Yeditepe University, Turkey)
}

\begin{abstract}
At EU level, measures to promote research and innovation became concrete with the creation of the European Research Area and the issuing of the White Paper on Governance in 2001. These were measures to tackle low economic growth and unemployment and to boost European innovation with the aid of science and technology. Nevertheless, the economic crisis of late 2008 has halted this process and exposed the lack of convergence across European and neighbour countries in innovative performance. Moreover, economically more affected countries have abandoned innovation policies as part of the austerity policies precisely dictated by the EU bureaucrats. This paper first discusses the EU policies towards the creation of the knowledge society and the effect of the crisis in relation to research and development. Secondly, the paper will analyze the case of Italy and how it has failed to keep up with some of its other European neighbours in terms of investment on knowledge, arguing that lack of such investment make countries less equipped and more dependent on knowledge generated in other places.
\end{abstract}

\section{Introduction}

Measures to promote research and innovation became concrete with the creation of the European Research Area and the issuing of the White Paper on Governance in 2001. The intent was to lift the EU, as an economic area, to the level of US and Japan in terms of competitiveness and innovation matching scientific performance with technological and industrial results, known as the European paradox. The Community Method was introduced to improve research framework and the Framework Programme was employed to promote greater science and technology collaboration and coordination. New understandings of society, as the result of the growing importance of information and the production and usage of knowledge in the 1990s, influenced the Commission approach.

The idea to invest in knowledge and research to promote innovation and therefore, the transition to a knowledge society, was first conceived at national level. In Finland the Science and Technology Policy Council published reports on the innovative society in 1993 and on the knowledge-based society in 1996. In the UK a report was published on how to benefit from the processes of privatisation and marked based reforms but lacking in competitiveness was published in 2003. In France arguments were proposed about the new economy and looked at the USA Information and Communication Technologies developments with the help of research and development, financing mechanism and deregulation of old monopolies. In the Netherlands an innovation platform was launched in 2003, the mission of which was to strengthen the innovation potential to secure a leading role for the country in the European knowledge economy of 2010.

Relevant, within this context, are the theories which attempt to understand the transformations within contemporary societies which begun in the 1960s and 1970s. Some argued for the emergence of new ways to understand contemporary societies with the central role of information and knowledge in society at least for the past forty years (Castells 2000; Sörlin and Vessuri 2007; Webster 2007; Fuller 2002; Lash 2002). The seminal work of Müldür and Caracostas, Society the Endless Frontier (1998), often considered as the blueprint for the FP6, pick up these theoretical changes and set the basis for the role of science and technology for the improvement of society. Many social scientists have recognised US, Japan, Britain and Germany as information societies and thus the EU urging for adjustment to the global information society.

An important factor for competing in the global economy is the investment in knowledge based capital. Investment in knowledge has been rising in many OECD economies because such an investment can be a source of return to scale in production and some of the knowledge such as research and development can also influence other parts of the economy.

However, it is argued that the lack of convergence of innovation investment can affect the cohesion process within the EU because of making less equipped countries dependant from knowledge produced elsewhere and at the same time put these countries in a less advantaged position to obtain such knowledge. This may be the case of Italy if we consider its poor performance in investment which pre-dates the international financial crisis, but also the effects that the crisis has had on innovation policies due to the austerity measures partly imposed by Brussels in order to contain the country public debt.

In the light of the EU policies, this paper will first acknowledge the recommendations of the White Paper on Governance of 2001, specifically issued to try to level the gaps of more diverse countries in terms of innovation and technological development, and the effects of the crisis on such measures. Secondly, it will be discussed the 
inclusive/exclusive character of the knowledge society and the situation of Italy as a potential excluded country from a possible knowledge society at EU level.

\section{EU and the Development of Innovative Performance Policies}

At EU level, in the light of the societal challenges at the end of the 1990s, policy makers, at The Lisbon Council of March 2000, assessed the strengths and weaknesses of the EU. Strengths were macro-economic prospects, growth and job creation, but the weaknesses were the development of key sectors and human capital formation. There was low employment rate, low participation in the labour market of women and older workers, and market regional unemployment disparity across the Union. A report on the socio-economic research activities 1998-2002 exposed the challenges of assessing the social and economic aspects of the European Research Programmes because of 'lack of commonly agreed definitions, consistent dataset and robust assessment methods.' This was an assessment of the socio-economic importance of FP5. The report analyses the Key Action role to improve the socio-economic knowledge based with the main themes as sated above. This part of the programme focused mainly on social sciences and one of the concerns was to prepare the research community to work effectively within the ERA and help the transition to the FP6. Amongst the objective was that of strengthen the contribution and the structuration of the social sciences and the humanities in the ERA. Due to the state of the state of social science research, largely performed at national level and by individual researchers one of the challenges of FP6 was the ability to collaborate within a large community of researchers.

The creation of the European Research Area was proposed in the year 2000 by the Commission Communication which stated that the $21^{\text {st }}$ century would be a century of science and technology and investing in research and technological development was a must for the future. The communication also pointed out the necessary conditions to increase the impact of research though the coordination of research and policies in Europe. The March 2000 Lisbon Council set the objective and implementation timetable and the resolution for the European Council called on the Commission in cooperation with the member states to present objectives and methodologies to articulate excellence in all member states and coordinate science policy (Patricio 2004:53).

The European Research Area communication and the EU White Paper on Governance were an attempt to provide the necessary ground for closer relationship also between social scientists and policymakers. In the context of these new approaches there were the political transformation of the EU due to the enlargement and the efforts to make the EU more democratic.

The reasons for the creation of the knowledge society at EU level were first felt at national level in Europe particularly in Northern European countries which saw in technology and innovation a way to economic growth. At EU level is crucial the Lisbon Strategy and the subsequent creation of the ERA and the inclusion of the social sciences. It was acknowledged that knowledge was plying an important role for research, innovation and education. As an instrument for the generation of knowledge the social sciences were included in the FPs to deal with the challenges including economic and political integration, economic growth and large scale migration faced by the EU and member states. The creation of the ERA and the various attempts at EU level to coordinate research also in the field of the social sciences and the relation with the policy making process with the technoscience approach can be seen as an approach to give more legitimacy to the EU policy process through the generation of scientific knowledge.

\section{Innovation Policies and the Economic Crisis}

Archibugi and Filippetti (2011) argue that the lack of convergence of innovation investment can affect the cohesion process within the EU because of making less equipped countries dependant from knowledge produced elsewhere and at the same time put these countries in a less advantaged position to obtain such knowledge. In fact the White Paper on Governance of 2001 was specifically issued to try to level the gaps of a more diverse in terms of innovation and technological development.

Another factor, however, which can aggravate this gap in knowledge across the EU, is the effect of the economic crisis on investment in research. According to a study from the Directorate General Research, the impact of the crisis on the real economy has diminished some aspects of investment in research particularly in new member states. For instance, research and development expenditure has diminished in Italy, Hungry, the Netherlands, Ireland, Slovenia and Slovakia. In Italy and the Netherlands public expenditure has not decreased in other public sectors. This means that research and development public expenditure in these countries is not a priority like in others, particularly Northern countries such as Finland and Sweden. In fact the 2010-2013 GBAORD of countries such as Italy and Spain but also UK and the Netherlands have changed in a negative way. This negative trend is also followed by decreased in higher education expenditure since 2009, which together with negative net-migration and brain drain can worsen the situation of human resources (Izsak et all 2013).

In order to show the changes that the economic crisis caused, it is also useful to see the division of EU countries into four groups, according to innovative performance. The Parvenu, including Poland, Slovakia, 
Lithuania, Bulgaria, Romania, Slovenia, which although they do not have a previous tradition of national innovation system, they have increased their investment; the Aristocrats, including Austria, Germany, Finland and Belgium which continue their commitment to investment in learning and innovation and also at the same time they are increasing during the period of crisis; the Decline Nobility, including Denmark, Ireland, UK, France and the Netherlands which have a tradition of national investment in national innovation but have not increased much over the earlier period of crisis; the Third State, including Hungry, Latvia, Czech Republic and Italy, Spain and Portugal, which are characterized by low national innovation and also low investment of private firms (Archibugi and Filippetti 2011).

In this division of countries it is possible to see how across Europe investment in research is heterogeneous. These differences are characterised by the relatively new EU member states which although they did not have a tradition in investment and innovation they have generally increased their investment also in a period of crisis. On the other hand, countries in the last group did not have a good performance before the crisis and have not adopted investment in research during the economic crisis. The growing disparity between EU countries in terms of investment in research and innovation jeopardises the intent to create a knowledge society within the EU and it also places, within such model, in a weaker position countries which are in a way excluded from such practices. This can be also translated in compromising EU integration in terms of economic competitiveness and economic and political cohesion.

\section{Inclusion/exclusion in the Knowledge Society}

The various interpretations of the knowledge society account for the effects and influences of knowledge and information on the political, social, economic and cultural aspects of society. In these interpretations, it is stressed that the passage from industrial societies to other forms of societies has been strongly influenced by knowledge/information and technology. These transformations have been encapsulated in the term knowledge society which is related to social processes, actors, learning processes and elements such as values, languages or social representation involved with the production, storage, manipulation and diffusion of knowledge. Knowledge is growing in importance and it affects society and the economy, and the two have different values and understanding of the role of knowledge (Sörlin and Vessuri 2007:2). The concept of post-industrial society exposed by Daniel Bell (1973) emphasises the role of information and knowledge. Lundvall (1996) with the learning economy also argues for a crucial role of knowledge and learning, but above all a new theoretical approach to better understand the role of 'technology, skills, preference and institutions' considered outside the explanation of economic development.

There are, nevertheless, also analyses which emphasises the inclusive/exclusive character of the knowledge society. For instance, Manuel Castells calls these different interpretations related to social, technological, economic and cultural transformations the 'network society'. He also recognises the passage from industrial to information age, related to information technologies of communication and also biological technologies. According to him information has replaced energy in determining productivity but also for the elimination of space, as it can be seen in globalization, and for the 'real time feature of communication'(Castells 2000:176).

Castells argues that information is, and has been important in all societies but in the new 'network economy' information becomes important in economic productivity. Different topical information, such as international politics and climate change can inform the flow of capital and became an important factor in economic productivity. The importance of information in society is not new, but it is the 'informational shift' to the manipulation of information to increase productivity and the 'action of knowledge upon itself' which constitute a new practice (Castells 2000b:17).

Although organizations are situated in places, the logic of the network is 'placeless' and it depends on the 'space of flows' which characterises information networks' (Castells and Nyiri 2004: 23). This dimension challenges the space of places such as regions, communities and nation states. In this context power is separated from political representation, production from consumption and information from communication. It is this inclusion/exclusion that, according to Castells, displaces people and territories domination depends on the capacity of elite to articulate and disarticulate the masses. To interact with the dominant networks also means to accept the goals of those networks.

This demonstrates that knowledge has an effect on the organization of society and that knowledge should be managed and not left to grow uncontrolled (Fuller 2002:2). Although knowledge is considered to be a good it is also argued that knowledge can be influenced by interests of how knowledge interact with society, become political (Sörlin and Vessuri 2007:1) and have implication for the production, diffusion and consumption. Furthermore, issues about the role of knowledge permeate the sphere of science policy and academia, and globalization and competitiveness.

The way knowledge and information may affect and transform societies, are also reflected in the relationship between science and technology and consequently science and society. This has resulted in what Fuller calls 'management of knowledge', where private corporations are involved in the business of knowledge. If 
knowledge is influencing the various spheres of society, questions may rise about the nature and provenience of such knowledge. In the Western tradition, knowledge and its pursuit is conceived for 'its own sake' (Fuller 2002:2) and knowledge thus is considered as a 'public good'. In the context of innovation and 'knowledge management' such a conception of knowledge production is not welcomed since innovation would be welcomed only in terms of profit putting to an end to research. In this way 'capturing knowledge' takes over its cultivation.

\section{Research and Development Italy and the Economic Crisis}

In Italy, at institutional level, research, through the various public programs, inter-ministerial committees and ministries, has been in the discourse of the policy making process. In fact, Italy is amongst the countries with Finland, Sweden, UK, Holland and Germany which gives high importance to research policy. The promotion of research for policies is also strongly encouraged by EU policies which have an impact on Italian research planning. Governmental bodies fund mainly unemployment and economic issues and academic research.

Research policy is given importance in the PICO (National Reform Program for Innovation Growth and Employment) with 12 strategic initiatives. In fact research policy is in the discourse of policy formulation and it is supervised by the CIPE (Inter-ministerial Committee of Economic Planning) and the MIUR (Ministry of University and Research). MIUR operates through specific funds for universities, public research agencies FRA (Fund for Applied Research) and FIRB (Basic Research Investment Fund) and fiscal automatic incentives.

The main elements of research policy are in the National Research Program and they cover the promotion and development of human capital also through the implementation of $\mathrm{PhD}$ programs and financial support to $\mathrm{PhD}$ courses in collaboration with other countries. Support for basic research is provided through the implementation of public project funding such as PRIN (Projects for relevance of National Interests), links between ordinary funds and university and scientific productivity of academic personnel, support for mission oriented programs (FIRB), support for Italian participation in the preparation of EU FPs, support for industrial research and support for research and development regional programs. The main mission of policy instruments are the development and improvement of human capital, the promotion of excellence in fundamental research, pursuit of multidisciplinarity and internationalization, collaboration between private and public agents and the use of results evaluation. In few words, the approaches and the tools set up to promote research are in line with the general approach that can be found in most advanced modern societies and at EU level.

The Monti government, in 2011, introduced innovation relevant for the research and innovation based on budget cut and the rationalization of the main research funds. The measure includes 'innovations for indirect financing and demand driven innovation in the main research areas'. Some innovations also include the 'decline of ordinary non-competitive funds', more integration in European Research and Development and simplification of the main research funds. The establishment of the Digital Agenda in 2012 ensures the alignment with the European Digital Agenda and will deals with Research and Development projects.

However, despite these measures, Italy faces some challenges in the sphere of research and innovation. Firstly, there are insufficient reforms and performance of the higher education system and there is low share of skilled human capital. The higher education system lacks financial and human resources and the effects of the crisis on the finances of the government are impeding future development. According to Eurostat, in Italy public expenditure on research and development as percentage of GDP, GBAORD, was $0.56 \%$ in 2011 , below the EU level of $0.73 \%$. In 2012 the estimated level of GBAORD continued to decline, reaching a GDP ratio of only $0.53 \%$ (OECD).

Eurostat figures for 2011 confirm the issue of unskilled human capital. In Italy the share of persons aged 30-34 with tertiary education attainment reached only $20.3 \%$, significantly below the EU27 average, 34.6\%. Eurostat data also stress the lack of high-tech sectors in Italy: the number of employees in high-tech sectors (hightechnology manufacturing and knowledge-intensive high-technology services) as percentage of total employment is only 3.3\%, below then EU average (3.8\%). The major barriers to the implementation of ERA objectives in Italy are represented by the low investments in research and development, and by the effects of the financial crisis.

\section{Conclusion}

The initial intent of the EU to create a space dedicated to the development of the knowledge society, in order to promote and facilitate integration, was realised with the creation of the European Research Area and thus, the importance of investing in knowledge. This goal was also intended to boast the economies of the EU to compete with the other important economies in the world. This approach has nevertheless been compromised by the economic crisis of 2008 which affected the economies of European countries and furthered impeding the idea of a European knowledge society. In fact, the crisis has changed the investment priorities of many European countries which in turns have to deal with austerity measures in order to keep under control their state 
expenditures. These measures are also part of economic measures dictated by the EU commission with the intent to keep under control more unstable economies of the EU area.

Nevertheless, this situation has also compromised the already divided attempt to create a knowledge society at EU level. According to different analysis of the role of knowledge in society, there are also interpretations which warn about the exclusive character of knowledge in the network society as well as the management of knowledge driven by private interest. If the development of knowledge and the management of information relates only to particular elites and interests, it means that groups or territories which do not invest, are left out or excluded from such developments. Apart from the problem of profit, related to the production of knowledge as opposed to the understanding of knowledge as a public good, countries which do not take part in the development of a knowledge/network society will in the long run depend on the knowledge developed elsewhere. This may be the case of Italy which being one of the six funding members of the EU (at the time the EEC), its lagging behind in investment for research and innovation may well relegate it outside the network and be dependent on outside knowledge or not to be able to benefit from the knowledge available. The reason for such exclusion is mainly related to lack of investment in the knowledge society and also in scientific research. Indicative is the fact that in Italy higher education students are diminishing also because research is not adequately funded. In addition there are elevated bureaucratic impediments which also prevent foreign university and students who want to make research in Italy. The paradox is that because of the financial crisis Italy has worsened its commitment in research and development and at the same time one way to overcome its economic and political crisis is indeed greater investment in the knowledge society.

\section{References}

- Archibugi, D. and Filippetti, A. 2011 "Is the Economic Crisis Impairing Convergence in Innovation Performance across Europe?" Journal of Common Market Studies

- Bell, D. 1976 The Coming of Post-Industrial Society: A Venture in Social Forecasting. Harmondsworth Penguin.

- Castells, M. 2000a The Rise of the Network Society, Second Edition. U.S.: Blackwell Publishing.

- Castells, M. 2000b The Rise of the Network Society, Second Edition. U.S.: Blackwell Publishing.

- EU Commission, The overall socio-economic dimension of community research in the fifth European Framework Programme European Commission 2003.

- EU Commission Towards a European Research Area Commission Communication (2000)

- Eurostat 2013 Annual data on employment in technology and knowledge-intensive sectors at the national level.

- Fuller, S. 2002 Knowledge Management Foundations Butterworth-Heinemann Boston

- Izsak, K., Markianidou, P., Lukach, R., Wastyn, A. (2013). "The impact of the crisis on research and innovation policies". Study for the European Commission DG Research by Technopolis Group Belgium and Idea Consult.

- Lash, S. 2002 Critique of Information Sage London

- Lundvall, B. A. (1996). "The Social Dimension of the Learning Economy". Druid Working Paper No. 96-1. http://www3.druid.dk/wp/19960001.pdf (01-03-2008)

- Müldür, U. Caracostas, P. (1998)."'Society, the endless frontier a European vision of research and innovation policies for the 21st century". European Commission, Directorate-General XII-Science, Research and Development.

- OECD Science, Technology and Industry Scoreboard 2013 http://www.oecd.org/italy/ 12-03-2014.

- Patricio, T. (2004) "Challenges facing social sciences in EU science policy" in Re-inventing the Social Sciences OECD 2004 http://www.oecd.org/dataoecd/46/45/33695704.pdf 21-05-2007

- Sörlin S. and Vessuri H. 2007 Knowledge Society vs. Knowledge Economy: Knowledge, Power, and Politics. Palgrave Macmillan.

- Webster, F. 2006 Theories of the Information Society Routledge London and New York. 